\title{
Why a DSM diagnosis of postpartum psychosis is important for women in the US legal system
}

\author{
Ann M. Rhodes ${ }^{1}$ \\ Published online: 20 August 2021 \\ (c) The Author(s), under exclusive licence to Springer-Verlag GmbH Austria, part of Springer Nature 2021
}

In the USA, mothers who kill their children are charged with murder under the criminal code of the state that the alleged crime occurred. There are several possible outcomes for a woman accused of murder. If the prosecution doesn't have sufficient evidence to prove guilt, the case will be dismissed for lack of evidence. The woman can plead guilty during the process of preparing for trial. If the case goes to trial, she can be found guilty, not guilty (acquitted), or found not guilty by reason of insanity.

In the USA, insanity is defined by one of two rules adopted by states that retain the insanity defense. Six states have essentially abolished the insanity defense: Idaho, Kansas, Montana, Nevada, North Dakota, and Utah (In those states, a person may be found "guilty but mentally ill and be sentenced to treatment before going to prison.). Of the states that don't have the insanity defense, all but North Dakota have the death penalty. Thus, it's possible for a woman who kills her child while suffering from postpartum psychosis (PPP) to be put to death as punishment for a crime committed during a psychotic episode without being able to assert an insanity defense.

Most states allow an insanity defense and the definition of insanity is based on one of two rules. The first, the M'Naghten Rule, used by the majority of the states, is derived from an old case in England. It requires that a person "be laboring under such a defect of reason, from disease of the mind, as to not know the nature and quality of the act he was doing, or, if he did know it, that he did not know what he was doing was wrong." (Daniel M'Naghten's case 1843, p. 210). This standard requires a complete loss of cognitive functioning and inability to recognize the wrongness of an act.

The second rule is based on the Model Penal Code (American Law Institute 1962). This allows a somewhat

Ann M. Rhodes

ann-rhodes@uiowa.edu

1 College of Nursing, University of Iowa, Iowa City, IA, USA expanded insanity defense, applying it to individuals who have a "substantial loss" of cognitive functioning rather than a complete loss. It states, "a person is not responsible for criminal conduct if at the time of such conduct as a result of mental disease or defect he lacks substantial capacity either to appreciate the criminality of his conduct or to conform his conduct to the requirements of law" (American Law Institute, Model Penal Code 1962, 4.01, Sect. 4).

In the USA, criminal defendants are presumed innocent, meaning that prosecutors must prove, beyond a reasonable doubt, that the crime was committed by that person. Prosecutors must prove guilt by showing evidence of two elements: the act (actus reas) and the intent (mens rea). Mens rea requires knowledge of one's actions at the time they are committed and understanding that the act was wrong. This means that a woman must have specific intent to commit the acts that resulted in the child's death. Criminal defendants are also presumed sane, meaning that the defense must prove that a mother was insane at the time the child was killed. In asserting an insanity defense based on postpartum illness, it is essential that a defense attorney have two types of evidence: a documented diagnosis of a mental illness and evidence of a woman's behavior before and after the crime demonstrating an inability to form specific intent. The defense must show that the woman was unable to understand what she was doing or did not know it was wrong. The exception, the "deific decree doctrine," holds that if a woman believed that she was commanded by god to commit an unlawful act, any commandment from god is necessary a delusion and the woman must be exonerated (Morris and Haroun 2001).

In many countries, infanticide statutes often result in more lenient sentences and require psychiatric treatment (Rhodes and Segre 2013), thus eliminating the need for a distinct PPP diagnosis. However, in the USA, attempts to replace the insanity defense with infanticide laws have not been successful. Thus, in the US legal system, the lack of a specific diagnosis of PPP in the DSM-5 (American Psychiatric 
Association 2013) presents a significant legal disadvantage. Although the current nosology includes "postpartum onset" as a "specifier" to the diagnosis "Brief Psychotic Episode," this diagnosis is not compelling to most courts or lay juries. An "onset specifier" is not a specific, identifiable diagnosis with characteristic symptoms and behavior which are necessary to support a defense of insanity. The lack of a definite PPP diagnosis thus makes assertion of an insanity defense difficult and impairs her right to a fair trial. By implication, the converse, i.e., having distinct diagnosis of PPP, would provide a stronger legal argument.

An Iowa case, Anfinson v. State (2007), is illustrative. Heidi Anfinson's 15-day-old baby drowned in the bathtub and was found weighted with rocks in a nearby lake. Despite her family's statements that her behavior was erratic and disturbing, Anfinson's attorneys did not introduce evidence that supported a plea of brief psychotic episode with postpartum onset at the time of her infant's death. Instead, they argued that the baby's drowning was accidental. She was convicted of second-degree murder. The Iowa Court of Appeals found that her attorneys rendered ineffective assistance when they failed to investigate evidence of her emotional state and the court ordered a new trial. However, Anfinson waived this right, pled guilty, and was sentenced to serve 50 years in prison. It is not unreasonable to conclude that the availability of a distinct diagnosis of postpartum psychosis would have resulted in more fair treatment of this ill and grieving mother. As Spinelli noted "Our reluctance to place postpartum disorders within a diagnostic framework often leads to tragic outcomes for women, family, and society" (Spinelli 2005, p. 19). To conclude, a distinct PPP diagnosis would represent a significant legal development for US mothers.

\section{References}

Anfinson v. State. 714 N. W 2d (Iowa Ct. App 2007)

American Psychiatric Association (2013). Diagnostic and statistical manual of mental disorders (5th ed.) Arlington, VA: Author

American Law Institute, Model Penal Code 1962) Article 2, sec 2.02

Daniel M'Naghten's case (1843) 8 Eng. Rep. 718, (U.K.H.L.)

Morris GH, Haroun A (2001) God told me to kill: religion or delusion? San Diego Law Rev (4):973-1050

Rhodes AM, Segre LS (2013) Perinatal depression: a review of US legislation and law. Arch Womens Ment Health 16:259-270

Spinelli MG (2005) Infanticide: contrasting views. Arch Womens Ment Health 8:15-24

Publisher's note Springer Nature remains neutral with regard to jurisdictional claims in published maps and institutional affiliations. 